\title{
Learning from Flint: How Matter Imposes Itself in the Anthropocene and What That Means for Education
}

\section{Catherine Milne, Colin Hennessy Elliott, Adam Devitt, and Kathryn Scantlebury}

James Lovelock in Gaia: A New Look at Life on Earth (1995/1979), described how his idea for Gaia emerged when he was working at the Jet Propulsion Laboratory in California in 1965. Collaborating on a team that was tasked with developing a series of experiments to look for life on Mars as part of the Voyager project, the planned experiments consisted of an automated microbiological laboratory designed to sample the Martian soil to see if it was suitable for simple microscopic life and exploratory examinations of Martian soil to see if the soil contained chemicals that might indicate "life at work," including amino acids and optically active substances (p. 2). After a year, Lovelock

\footnotetext{
C. Milne $(\varangle)$

Department of Teaching and Learning, New York

University, New York City, NY, USA

e-mail: catherine.milne@nyu.edu

C. H. Elliott

Department of Instructional Technology and Learning Sciences,

Utah State University, Logan, UT, USA

e-mail: che217@nyu.edu
}

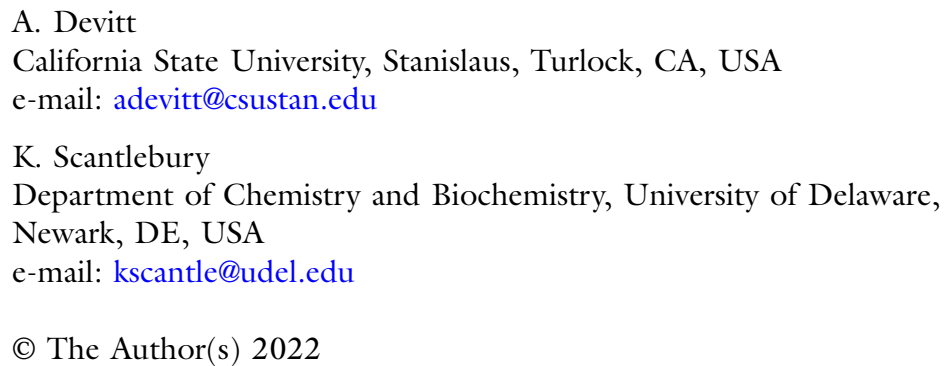

A. Devitt

California State University, Stanislaus, Turlock, CA, USA

e-mail: adevitt@csustan.edu

K. Scantlebury

Department of Chemistry and Biochemistry, University of Delaware, Newark, DE, USA

e-mail: kscantle@udel.edu

(C) The Author(s) 2022 
started to ask questions that had not specifically been a focus of the scientists collaborating on this project including, "How do we know that life on Mars will reveal itself to tests based on life on Earth? What is life and what tests will tell us that there is life?" When other scientists there asked him how one might answer these questions, he suggested they would look for entropy reduction, since the ability to organize is a feature of living things. For Lovelock, this discussion initiated an ongoing exploration of the relationship between the material and the living in the world. In the 1960s, Lovelock was already grappling with the issue of the entanglement of the geo and the bio, matter and life, which has become of the mainstream focus of scientists like Robert Hazen (2012), who argue that life and matter are entangled and that the evolution of matter and life have shaped the Earth-an Earth which humans often seek to claim for themselves. Lovelock's thinking might lead you to think that science has not only been considering the entanglement of life and matter but has begun to move in that direction. However, as we show in this chapter, drawing on the effectivity of water as a solution, humans tend not to notice matter unless it brings an effect upon them.

\section{Effectiveness, Agency, And the Anthropocene}

In 2000, Paul Crutzen (1995 Nobel Prize co-winner in chemistry for his research on ozone depletion) and Eugene Stoermer (2000) published a statement, "an affirmation that our species belongs amongst other biological and geological forces" and with that claim, they proposed "the term "Anthropocene' for the current geological epoch" (p. 17), superseding the current geologically accepted Holocene ("Recent Whole") epoch. Their rationale for a new epoch was based on an analysis of the impact that the expanding human population was having on earth's resources. Simon Lewis and Mark Maslin (2015) claim that it was Crutzen and Stoermer's argument that the Anthropocene had already begun, which galvanized an increase in the usage of this idea and term. As Stacy Alaimo (2019) notes, the Anthropocene, as a claim for human exceptionalism, is both illuminating and misleading; illuminating, because it acknowledges the implications for global phenomena of taking seriously the intra-action between living (human) and nonliving and calls into question the separation of nature and culture that structures modernity, and misleading because it grants humans an exceptional status that is not assigned to any other living thing.

Of course, the presentation of "the Anthropocene" as part of the geological timescale is easy to critique, especially if it seems to come from a position of human hubris. Lewis and Maslin (2015) acknowledge that from a geological perspective, human activity is fleeting and recent. However, there can be no denying that human activity is speeding up the rate of change in a number of different contexts. If we accept that the issue is not only that science is coming around to the idea that the ontology of the Earth is an outcome of bio, geo, 
and chemo intra-actions but also that humans are not central, exceptional, or separate from nature, then what are the implications of such a stance?

Isabelle Stengers $(2010$, p. 7$)$ notes, the category of human "has never been neutral because it entails human exceptionalism at its crudest... From this standpoint, the very drastic opposition between humans and nonhumans would then itself be the witness of the unleashed power of this (nonhuman) idea that made us humans, as it allowed us to claim the exception, to affirm the most drastic cut between those beings who 'have ideas' and everything else, from stones to apes." So, it was the unleashed power of the non-human that allowed humans to claim this undeserved exceptionalism? According to Sarah Whatmore (2006, p. 602) the "livingness" of the world shifts matter, "from indifferent stuff out there, articulated through notions of 'land,' 'nature,' or 'environment' to the intimate fabric of corporality that includes and redistributes the 'in there' of human being." In Inhuman Nature, Nigel Clark (2011, p. 15) argued that the proposal for the Anthropocene constituted for Crutzen and Stoermer (2000) requires more than an appreciation that humans are part of the biological foment. It requires that scientists invest in a version of relationality in which observable realities are understood in terms of entanglements that are inescapable and inseparable, mutually interdependent, and relationally co-constitutive. However, as Melinda Benson (2019) notes, in science and in the everyday world, "the dominant ontology reinforces a familiar binary-one in which humans are separate from and doing things to nature" (p. 252). This ontological stance, which emerged during the Enlightenment, underlies environmental laws in the United States. As Benson observes, this ontology, and the associated laws, make assumptions about agency, which is assigned to only humans, and exceptionalism, which we have already noted. If humans persist with this ontological stance then cultural, government, and political strategies designed to address environmental challenges are likely to be limited in their effects.

Benson (2019) argues for the need to engage in practices and processes that "more accurately reflect our lived experience of the material world" (p. 254). Indeed, since the 1980s Earth system modeling has recognized the interrelation between bio (including humans), geo, and chemistry elements. However, when researchers argue for the need for Earth system models "to address explicitly the inter-actions between the ecosphere and the "anthroposphere"" (Scholze et al., 2012, p. 131), one is left to acknowledge that the underlying stances of agency and exceptionalism remain unexamined and unproblematized in much of this work. In an exploration of the Rio Grande Forest System, Benson explores the need to decenter the human and "rather than seeing wildfires, flooding and other events as problems to be solved" (p. 276) or as "disasters," beginning with an exploration of the roles they play as actors in the system with humans in relational engagements with all elements and processes. In this case, we take Jane Bennett's (2010) notion of agency as effectivity rather than intentionality seeing agency as relational, when entities, 
material and human, intra-act, engendering phenomena that may be unpredictable. Benson sees the proposal of the Anthropocene not just as a geological epoch but as an opportunity to restructure human intra-action in the space time mattering of the Earth (Barad, 2007).

\section{A Molten, More-than-Human World}

However, for many people matter only comes to their attention when they encounter an ontological disturbance where matter forces itself on human experience and thus is noticed. The more-than-human world becomes "molten" and leaks into everyday experiences as the material world imposes itself on the everyday world of most human agents (Whatmore, 2013). In this chapter, we use the water crisis of Flint, Michigan, to explore when the material leaked into humans' everyday world to cause an ontological disturbance through water and other elements of the material more-than-human world, such as lead ions, legionellosis (Legionnaire's disease), corrosion control, and water pipes.

Flint is a city in the "rust belt" of the United States with a majority Black population. It was once a thriving economic city (although people knew little of the ecological costs) in an area that was the industrial heartland, where steelmaking and associated industries fueled the country's economic growth in the mid- to-late twentieth century. At one time, Flint was a focus of industry. In 1908, General Motors (GM) was founded in Flint, but by the end of the twentieth-century GM had closed most of its factories, which had a flow-on effect to other industries associated with the auto industry and small businesses supporting the community (Clark, 2018a). Nearly 50\% of the populace left Flint, and one consequence was a decline in tax revenue for local government to run utilities and maintain infrastructure. Concurrent with a decline in local tax revenues, the state of Michigan reduced fiscal support to its cities, and by 2008 , the Great Recession had a devastating impact on government budgets.

\section{The Cost of Water}

Not too long after the financial crisis hit the state of Michigan hard, Rick Snyder-a venture capitalist with no governmental experience-was elected governor in 2010. Early in his term, he declared the City of Flint in financial crisis and appointed an emergency manager, which effectively got rid of local governance for any fiscal decision-making. In early 2013, the managers of Flint decided to change the source of its water from the Detroit Water and Sewage Department (DWSD) to a pipeline from the newly formed Karegnondi Water Authority (KWA), which planned to extract water from Lake Huron and pipe the water to cities in order to save money. Centering the water in analysis of the cascading policy moves reveals that the consequences of this decision were not just a material-human connection but unfolding agency of the Flint River water infrastructure, which co-constitute each other in the toxic phenomena that followed. 
The cities were responsible for water treatment. However, the construction of the new pipeline was not scheduled until 2016, and the state-appointed emergency manager for the City of Flint decided that rather than continuing with the expensive DWSD, the city would use Flint River water treated at the defunct water treatment plant (Olsen \& Fedinick, 2016). In 2014, the defunct plant was reactivated and the switch from DWSD to Flint River water was made (Dingle, 2016). There were two main issues with this decision. Firstly, the Flint River is more corrosive than the water from Lake Huron, raising issues of corrosion control which should have been addressed before the water was released to citizens, and secondly, the treatment plant required refitting and updating and the appointment of skilled staff. Within weeks of the switch to Flint River water, Flint residents reported that their water had turned brown, tasted metallic, smelled foul, and people were experiencing skin rashes and hair loss (Clark, 2018a). Further, some pediatricians like Dr. HannaAttisha began recognizing high lead levels in Flint children's' blood. Yet, only Flint residents in the direct path of the contaminated water recognized the agency of the water and their entanglement with it. As Dr. Hanna-Attisha argues in her book about the crisis (2018), testing the children's lead levels is actually a test of their lived environment, including the water infrastructure. This intra-action led to a recognition of a debilitating problem that required immediate action. Yet the decision-makers failed to act. It was not just lead in the water that flowed out of Flint residents' tap but failed governmental policy and woeful disregard for the agency of residents. The events illustrated environmental racism. It took local activism and national recognition through President Obama's eventual declaration of an emergency to spur local officials into action.

For Flint residents, the water was leaking into their everyday experiences in unexpected but real ways. As Clark (2018b) noted, when the people of Flint complained that their tap water was odorous and made children sick, it took officials 18 months to accept that there was a problem, even as doctors, led by Hannah-Attisha, began noticing higher levels of lead in children's blood. The phenomena that emerged from the intra-actions between the dissolved chemicals and humans was initially rejected by state and local officials (Olsen \& Fedinick, 2016). Although high lead levels can exist without a change in water color, Flint's brown water was possibly the first indication of lead contamination (Torrice, 2016). A timeline of key events helps to communicate just how quickly the material world imposed itself on Flint (Flint Water Advisory Task Force [FATF], 2016). The FATF laid the blame for the Flint water event with replacing of local representative decision-making with state-appointed emergency managers. In April 2014, the City of Flint began distributing treated Flint River water to its customers ${ }^{1}$ and soon after residents begin complaining

\footnotetext{
${ }^{1}$ According to the Flint Advisory Task Force (FATF, 2016), the Michigan Department of Environmental Quality (MDEQ) determined that corrosion control, as legally required by the Federal Environmental Protection Agency's (EPA) lead and copper rule, was not
} 
about its odor, taste, and appearance. On July 1, 2014, Flint started its first sixmonth monitoring period for lead and copper in the drinking water. By August 15, 2014, discovery of E. coli bacteria violation led to a local boil water advisory and a month later, the Michigan Department of Environmental Quality requested an evaluation for trihalomethanes (disinfection byproducts) in the water. By October 1, 2014, the Genesee County (the county in which Flint is the largest urban center) Health Department communicated its concern to Flint Public Works regarding the detected increase in Legionnaires' disease cases since April 2014. In October 2014, General Motors announced that it would cease to use water from the Flint WTP, citing corrosion concerns related to chloride levels in water from Flint WTP. Of course, for Flint one of the issues was that the material which was implicated in the phenomena that Flint residents reported is submicroscopic and therefore difficult to engage with. Also, the phenomenon that residents and the water constructed could easily be ignored by city and state managers because, effectively, they were not elected officials and not directly answerable to the residents.

The agents that were responsible for all the observed phenomena are still not completely understood. In some cases, even if residents lived in relatively new houses that had plastic piping into the house, the piping that distributed water from the treatment plant used lead or iron pipes. These pipes require the formation of a phosphate preservation layer to stop the lead or iron from the pipes dissolving into the drinking water. This preservation layer is created through the continued use of a phosphate corrosion inhibitor $\left(\mathrm{PO}_{4}{ }^{-3}\right)$, which has the goal of stopping lead or iron from the pipe dissolving into the water as lead ions (e.g., $\mathrm{Pb}^{2+}, \mathrm{Pb}^{4+}$ ) and iron ions (e.g., $\mathrm{Fe}^{2+}, \mathrm{Fe}^{3+}$ ). The phosphate does this by reacting with the iron or lead in the pipe to form lead (II) phosphate or iron (III) phosphate that forms a crust on the inside of the pipe. This inhibitor needs to be added as an ongoing process because without the continual supply of phosphate, the crust corrodes. When Flint's city officials decided to use water from the river, they failed to add the phosphate corrosion inhibitor, even though they were legally bound to do so because of the federal Copper and Lead Rule, which limits the levels of copper and lead in residential tap water.

Compared to the water from Lake Huron, Flint River water contained more particles, ions, organic matter, and microbes. Flint River water was naturally high in chloride $\left(\mathrm{Cl}^{-}\right)$ions (Dingle, 2016). As soon as Flint water was used, any iron pipes in the water distribution system began corroding as the iron phosphate in any remaining preservation layer reacted with the chloride ions, releasing iron $(\mathrm{Fe})$ ions into the water. These iron ions then reacted with chlorine $\left(\mathrm{Cl}_{2}\right)$, (different from chloride ions) that was added as a disinfectant to kill any microorganisms in the water. The chemical reaction between

required immediately but instead the Flint Water Treatment Plant would carry out 2 sixmonth monitoring periods and then the MDEQ would make a determination about the need for corrosion control. 
iron ions and the chlorine in solution meant that the amount of chlorine was reduced, which forced the humans "overseeing" water quality to add more chlorine to control the coliform bacteria detected in the water (the presence of which indicated contamination from human and other animal fecal waste). While additional chlorine did control the bacteria, it also initiated the formation of trihalomethanes. The chemistry of trihalomethane formation is a little complex. When chlorine gas dissolves in water it forms a hypohalous acid. In water, this acid exists in equilibrium with hypohalite ion. In the case of chlorine, this would be hypochlorous acid $(\mathrm{HOCl})$ and hypochlorous ion $\left(\mathrm{OCl}^{-}\right)$. At low concentrations of the halide ion $\left(\mathrm{Cl}^{-}\right)$, formed when chlorine reacts with water, the reaction stops with the formation of $\mathrm{HOCl}$ and $\mathrm{OCl}^{-}$. The formation of the trihalo ion, $\mathrm{Cl}_{3}{ }^{-}$, which can form when more chlorine is available, does not take place to a significant degree (Boyce \& Hornig, 1983). Both $\mathrm{HOCl}$ and $\mathrm{OCl}^{-}$are powerful disinfectants for removing coliform bacteria. However, the addition of more chlorine in a more basic environment initiates a reaction between chlorine and chloride with the resulting formation of trihalomethanes, in this case trichloromethane. The same types of reactions occur with all halogen elements, most commonly chlorine and bromine. The presence of trihalomethanes was concerning because of their association with negative health effects and reproductive health (Hood, 2005). Specifically, with everyday tap use, absorption through the skin and inhaling these chloromethanes can strongly affect the level of trichloromethanes in the blood.

Flint city officials did not take matters seriously, resulting in negative consequences for the material and the people of Flint. Officials did not attend to the possible issues this water was creating for the people of Flint, the same way that General Motors did for its engine parts. General Motors, because it was of interest to their business, listened to the phenomena that their materials were producing and they switched their water supply. The state and city officials in charge of making decisions for the residents of Flint did not listen to the ways the materials in the water and their residents were speaking to them, even as the material world had become molten for residents, imposing itself on their everyday lives.

At each stage of the process from the water that was chosen, the treatments applied to the water, the pipes that transferred the water to homes, and the people and other animals that used the water as a source of nutrition and cleanliness, the matter was taken for granted. Human responses to the materials coursing through the water pipes of Flint constituted phenomena depending on how the material-discursive practices were enacted and how cuts were made to establish the boundaries. If the management had acted on water treatment as a phenomenon in which agents come together, this might have resulted in a more holistic approach to water delivery and treatment. As such, the goal of water delivery and treatment would have acknowledged the role played by ions, water, pipes, residents, and their bodies as belonging to a system of water functioning instead of prioritizing management efficiency and fiscal prudence. As this example illustrates, the submicroscopic agents in water 
have their own ideas about how they will react under certain circumstances. Perhaps this case is also suggestive of how science educators might rethink their construction of systems thinking and the Anthropocene more specifically. An earth system approach offers the possibility of removing humans from the center of the narrative, while engaging in the intricacies of the systems that produce phenomena like water running out of a tap.

\section{IMPLICATIONS FOR SCIENCE EDUCATION}

The so-called Flint Water Crisis is an illustrative microcosm of the increasing number of global challenges delineating human-Earth-chemistry intra-activity. The Flint Water Crisis, in combination with other examples, such as the Australian wildfires, Amazon deforestation, and most currently, COVID-19, epitomize the onto-epistemological stance of human exceptionalism undergirding human activity and worldviews. At the same time, we need to accept that all participants, living and nonliving, have agency and therefore participate in a complex and dynamic system that is distributed across multiple and overlapping bodies (Bennett, 2010). As we have argued throughout this chapter, we are living in a new epoch, the Anthropocene, where nature and culture are inherently entangled-yet, science and current visions of science education fail to engage with this worldview. Rather than constructing Flint and other examples as emergencies or crises that need to be solved, in a worldview where nature and culture are entangled, education would explore the dynamic nature of these events and the intra-actions of all elements. We need to transform what science education looks like for both developing scientists and everyday citizens.

In the USA, the public $\mathrm{K}-12$ educational system uses national standards to set the vision leading both curricular and instructional reforms. The current enacted vision of science education in $\mathrm{K}-12$ education is dominated by the Next Generation Science Standards (NGSS) (Lead States, 2013). In the NGSS, disciplinary science ideas and the practices of scientists (i.e., human activity) are presented as dis-entangled dimensions of science learning. NGSS aims to connect humans with nature through an exploration of disciplinary core ideas, the practices of scientists and engineers, and the relationships of crosscutting concepts among traditionally separated disciplines (Lead States, 2013). While NGSS attempts to reconcile the role of humans in the natural world, it still promulgates a unidirectional impact of humans on the earth and maintains human exceptionalism in that the standards only focus on science that centralizes the human and human agency in the world (Maslin, 2015). For example, consider the report, Using Phenomena in NGSS-Designed Lessons and Units, which begins with the statement, "Natural phenomena are observable events that occur in the universe and that we can use our science knowledge to explain or predict" (NGSS Lead States, n.d., p. 1). Note that, in this description, phenomenon exists naturally to be observed and explained by humans using science. We advocate a need to understand the perspective of 
the phenomena; in other words, rather than looking for phenomena from predefined constructs, understanding how phenomena emerge out of situations like the Flint Water Crisis and how phenomena is emergent as humans and the material world are entangled.

A new vision of $\mathrm{K}-12$ education needs to incorporate the role of intraactivity, nature, and human activity entanglements, making the emergent nature of phenomena explicit rather than telling learners what the phenomena is and then expecting them to recreate that example of phenomenon. For example, the human-nonhuman inputs in the phenomena of the Flint Water Crisis unfolded as the community intra-acted with the water and its unseen infrastructure, which only became "molten" and seeped into the awareness of the humans when the issues became visible and tangibly changed humans' lives. Flint water and the submicroscopic agents that were intraacting with human systems and initiating a range of emergent phenomena had negative implications for human health as a consequence of how the water came together with the pipes and how the political structures in the state of Michigan created positions for people to impose a new water source without community accountability. This series of intra-actions culminated in the contaminated (poisonous) water (sometimes brown in color, but also sometimes undetectable by the naked eye) that came out of Flint residents' taps.

Student learners under the present conception of NGSS, where life and physical science are dis-entangled from human activity, will most likely be inadequately prepared to understand the complexity of such challenges. While an important goal of NGSS is to prepare students to be problem-solvers (Lead States, 2013), essentialized knowledge and practices will deprive them of the criticality, knowledge, experience, care, and ethic they need to analyze the nuances involved in this situation and prioritize action. Learning continues to be theorized and practiced as a cognitive activity-where the "object" has an essence to become known by the "subject." By separating object and subject, this epistemology establishes the need for "representations" or concepts that are as like the object as possible but which need to be learned. This approach to education continues to influence how $\mathrm{K}-12$ science education and teacher education principally theorize how science is taught. The goal for students is to provide symbolic representations of requested phenomena. Particularly from anthropocentric epistemology, we no longer can pretend that phenomena "exist" in an objective form nor that students can learn about pre-determined phenomena in an objective totality.

Hetherington et al. (2019) take a material-dialogic stance for reframing science learning and, subsequently, suggest nuanced explanatory rationales for explaining why common $\mathrm{K}-12$ teaching tools and strategies are fruitful for teaching science. Explanatory frameworks for student learning, such as "visual learning," "making learning hands-on," or "adds motivation" saturate K-12 teachers' and teacher education discourses, whereas explanatory frameworks rooted in Barad's (2007) work would emphasize the role of material agencies 
intra-acting in the formation of student knowledge and pedagogical decisions. To illustrate, for example, the necessary intra-actions between phenomena and humans, Hetherington et al. (2019) rearticulate the role of students' gesturemaking during activity is evidence of material agency, "talking-back" (Schoen, 1996) shaping students' thought processes prior to typically desired symbolic representations of the phenomena (i.e., definitions, descriptions, formulas). From a dialogic-materialist perspective, gestures, which reverberate the voice of material, are recognized as significant communicative devices, whereas according to current assessment practices, only written, and in rare circumstances verbal, symbolic forms are worthy of evidencing meeting learning objectives.

Ultimately, the teaching and learning, and subsequently the materials used in assessment practices, matter. Likewise, experiments and activities are considered supportive of student learning because of the "hands-on" component but would offer more if the agency of the participating materials were acknowledged. A common experiment for students to explore conservation of mass is through observing ice cubes melting in a closed container and measuring the mass before and after the melting takes place. Yet rarely are learners asked to listen to what the ice cubes and the water and the container are saying to them. We argue that the framework of "hands-on" undermines any consideration of the role of scientists in how they engage in scientific work in real-world conditions, such as Flint Water, because this framework fails to provide a context in which consideration is given to the dynamic interplay between living and non-living in the emergence of phenomena that typically only become acknowledged when they become molten and seep into our awareness as they impose themselves.

Understanding the phenomena created in Flint necessitated a broad understanding of history, racism, classism, politics, and geography to appreciate what was pouring through the tap of residents of the Flint community. It was, in fact, everyday citizens, particularly mothers, who noticed how the phenomena of Flint water "responds back" to the human (Barad, 2012; Hetherington et al., 2019). They were the first to notice the discolored water, the smell, and the resulting rashes and hair loss of using said water. Likewise, auto workers working for General Motors (GM) in 2014 noticed that engine parts were corroding and swiftly switched water sources-an option that was not possible without the economic and political means. Rather than teaching facts, formulas, and demonstrations, we can learn a lot of scientific expertise and practices from people who are most impacted from crises, like the residents in Flint. Material-dialogism values the learning of new onto-epistemological frameworks that include social configurations, spatial relations, purposes, and the agential role of material resources. Such additional frameworks drastically enhance how teachers could reconfigure and be reconfigured when teaching science. 


\section{Listening to the Water and the People}

The officials' failure to respond to the challenge of Flint water was because they devalued the lives of the city's African American residents. Moreover, those residents whose economic lives were already impacted by the city's declining fortunes were excluded from the decision-making process, which included brutal financial accounting and fiscal austerity. Ironically, in late August 2020, the state of Michigan proposed at $\$ 600$ million settlement for Flint's residents (Bosman, 2020).

Bullard (2001) shows us that this kind of inequitable policy decisionmaking is consistent throughout environmental policy in the United States and around the world. Consistently, lower income neighborhoods and neighborhoods that are majority Black are exposed to more pollution and more detrimental environmental factors due to governmental policies and corporate decision-making. The Flint Water Crisis is another example of environmental racism (Bullard, 2001) and classism that emerges from the intra-action between histories of racial injustice, outdated infrastructure, and corporate/government decision-making for fiscal interests over humane conditions. Therefore, we believe a systems approach that deepens perspectives on how the human and material agents produce unfolding phenomena would actually lead to a more humanizing perspective for these kinds of policy decisions and further scientific practice. This would inform data collection systems for lead testing of humans that would offer easier integration across providers (HannaAttisha, 2018), as well the ways we teach and learn scientific knowledge making processes. So instead of just building "hands-on" science pedagogies, science education and education in general should be building pedagogies that critically engage in material agencies intra-actions and the political nature of knowledge together. What the Flint Water Crisis also shows us is that scientific perspectives are important for building critical narratives about ongoing policy and infrastructure issues, which the residents and activists took up because their health depended on it. Science standards, like the NGSS, therefore must take into account the unfolding, complex, and intricate ways that science, politics, and ethics unfold currently and a vision of change for a more onto-ethico-epistemologically focused future (Barad, 2007).

\section{REFERENCES}

Alaimo, S. (2019). Your shell on acid: Material immersion, Anthropocene dissolves. In R. Grusin (Ed.), Anthropocene feminism (pp. 89-120). University of Minnesota. https://doi.org/10.5749/j.cttlm3p3bx8.

Barad, K. (2007). Meeting the universe halfway: Quantum physics and the entanglement of matter and meaning. Duke University Press.

Barad, K. (2012). Nature's queer performativity. Women, Gender and Research, 1(2), 25-53.

Bennett, J. (2010). Vibrant matter: A political ecology of things. Duke University Press. 
Benson, M. H. (2019). New materialism: An ontology for the Anthropocene. Natural Resources Journal, 59, 251-280.

Bosman, J. (2020, August 19). Michigan to pay $\$ 600$ million to victims of Flint water crisis. The New York Times. https://www.nytimes.com/2020/08/19/us/ flint-water-crisis-settlement.html.

Boyce, S. D., \& Hoernig, J . F . (1983). Reaction pathways of trihalomethane formation from the halogenation of dihydroxyaromatic model compounds for humic acid. Environmental Science \& Technology, 17, 202-211.

Bullard, R. (2001). Environmental justice in the 21st century: Race still matters. Phylon, 49(3-4), 151-171.

Clark, A. (2018a, July 3). 'Nothing to worry about. The water is fine': How Flint poisoned its people. The Guardian. https://www.theguardian.com/news/2018/ jul $/ 03 /$ nothing-to-worry-about-the-water-is-fine-how-flint-michigan-poisoned-itspeople.

Clark, A. (2018b). The poisoned city: Flint's water and the American urban tragedy. Picador.

Clark, N. (2011). Inhuman nature: Sociable life on a dynamic planet. Sage.

Crutzen, P. J., \& Stoermer, E. F. (2000). The "Anthropocene." International Geosphere Biosphere Program Global Change Newsletter, 41, 17-18. http://www. igbp.net.

Dingle, A. (2016, December). The Flint water crisis: What's really going on? ChemMatters. https://www.acs.org/content/acs/en/education/resources/highschool/ chemmatters/past-issues/2016-2017/december-2016/flint-water-crisis.html.

Flint Water Advisory Task Force. (2016). Final report. Accessed on July 14, 2021 at http://flintwaterstudy.org/wp-content/uploads/2016/03/Flint-taskforce-report_2438442_ver1.0.pdf.

Hanna-Attisha, M. (2018). What the eyes don't see: A story of crisis, resistance and hope in an American city. One Worlds.

Hazen, R. (2012). The story of Earth: The first 4.5 billion years, from stardust to living planet. Viking.

Hetherington, L., Hardman, M., Noakes, J., \& Wegerif, R. (2019). Making the case for a material-dialogic approach to science education. Studies in Science Education, 58(2), 141-176. https://doi.org/10.1080/03057267.2019.1598036.

Hood, E. (2005). Tapwater and trihalomethanes: Flow of concerns continues. Environmental Health Perspectives, 113(7), A474.

Lewis, S. L., \& Maslin, M. A. (2015). Defining the Anthropocene. Nature, 519, 171-180. https://doi.org/10.1038/nature14258.

Lovelock, J. (1995/1979). Gaia: A new look at life on Earth. Oxford University Press.

NGSS Lead States. (2013). Next generation science standards: For states, by states. National Academies Press. www.nextgenscience.org/next-generation-sciencestandards.

NGSS Lead States. (n.d.). Using phenomena in in NGSS-designed lessons and units. https://www.nextgenscience.org/resources/phenomena.

Olsen, E., \& Fedinick, K. P. (2016). What's in your water? Flint and beyond. Natural Resources Defense Council.

Schoen, D. (1996). Reflective conversation with materials. In T. Winograd, J. Bennett, L. Deoung, \& B. Hartfield (Eds.), Bringing design to software (pp. 171-184). Addison-Wesley. 
Scholze, M., Allen, J. I., Collins, W. J., Cornell, S. E., Huntingford, C., Joshi, M. M., Lowe, J. A., Smith, R. S., \& Wild, O. (2012). Earth system models: A tool to understand changes in the Earth system. In S. E. Cornell, I. C. Prentice, \& J. I. House (Eds.), Understanding the earth system: Global change science for application (pp. 129-156). Cambridge University Press.

Stengers, I. (2010). Including nonhumans in political theory: Opening Pandora's box? In B. Braun \& S. Whatmore (Eds.), Political matter: Technoscience, democracy, and public life (pp. 3-33). University of Minnesota Press.

Torrice, M. (2016). How lead ended up in Flint's tap water. Chemical and Engineering News, 94(7), 26-29.

Whatmore, S. (2006). Materialist returns: Practicing cultural geography in and for a more-than-human world. Cultural Geographies, 13(4), 600-609.

Whatmore, S. (2013). Earthly powers and effective environments: On ontological politics of flood risk. Theory, Culture \& Society, 30(7-8), 33-50.https://doi.org/ $10.1177 / 0263276413480949$.

Open Access This chapter is licensed under the terms of the Creative Commons Attribution 4.0 International License (http://creativecommons.org/licenses/by/4.0/), which permits use, sharing, adaptation, distribution and reproduction in any medium or format, as long as you give appropriate credit to the original author(s) and the source, provide a link to the Creative Commons license and indicate if changes were made.

The images or other third party material in this chapter are included in the chapter's Creative Commons license, unless indicated otherwise in a credit line to the material. If material is not included in the chapter's Creative Commons license and your intended use is not permitted by statutory regulation or exceeds the permitted use, you will need to obtain permission directly from the copyright holder.

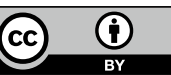

